\title{
Decreased Exercise Tolerance
}

National Cancer Institute

\section{Source}

National Cancer Institute. Decreased Exercise Tolerance. NCI Thesaurus. Code C119203.

A reduction in the ability to perform or withstand activities that induce physical or mental exertion. 